2. Krukovich E. V., Zhdanova L. A., Luchaninova V. N. Risk periods in the formation of the children and adolescents health. Pediatrics. 2007. No. 86 (2). P. 103-106.

3. Ostrovskyi I. M., Prokhorov E. V., Narizhnyi M. Yu. Health of children from the results of the parents' questionnaire. Russian Bulletin of Perinatology and Pediatrics. 2017. No. 62 (3). P. 105-111.

DOI https://doi.org/10.30525/978-9934-588-81-5-2.13

\title{
ДОСЯГНЕННЯ ПОЗИТИВНОГО СОЦІАЛЬНОГО РЕЗУЛЬТАТУ ДЛЯ НАСЕЛЕННЯ ВІД ВПРОВАДЖЕННЯ ГОСПІТАЛЬНИХ ОКРУГІВ
}

\author{
Стовбан М. П. \\ кандидат медичних наук, \\ дочент кафедри фтизіатрії і пульмонологіі \\ з курсом професійних хвороб, \\ заступник генерального директора
}

Комунальне некомериійне підприємство «Івано-Франківська обласна клінічна інфекційна лікарня Івано-Франківської Обласної Ради»

\section{Стовбан I. B.}

кандидат медичних наук, дочент кафедри сочіальної медичини та громадського здоров'я Івано-Франківський національний медичний університет м. Івано-Франківськ, Украӥна

\section{Толстанов О. К.}

доктор медичних наук, професор, професор кафедри управління охороною здоров'я Національна медична академія післядипломної освіти імені. П. Л. Шупика м. Київ, Україна

\section{Гбур 3. В.}

доктор наук з державного управління, професор кафедри управління охорони здоров'я Національна медична академія післядипломної освіти імені. П. Л. Шупика м. Київ, Україна 
Вітчизняні дослідники переконані [1, с. 129], що визначальною ознакою сучасної парадигми соціальної держави є дотримання принципів переорієнтації управлінської роботи органів влади на особистість, добробут громадян, а також безпеку і розвиток населення, що в сукупності визначає рівень соціального ефекту від здійснення регуляторних функцій державою. При цьому, максимізація соціального ефекту для населення від реформування сьогоденної системи охорони здоров'я, зокрема створення мережі госпітальних округів, можливе лише за умови дотримання теоретико-методологічних принципів. Узагальнюючи погляди дослідників можна визначити наступні науково обгрунтовані, а також законодавчо визначені засади роботи сфери охорони здоров'я: принцип рівнодоступності громадян до медичних послуг, що означає функціонування системи охорони здоров'я на засадах загальноприйнятих людських цінностей, притаманних соціальній державі [1, с. 129]; принцип демократизації державного управління в умовах реалізації медичної реформи [2, с. 211]; принцип законодавчо визначеного порядку надання медичних послуг та правового статусу пацієнтів [3, с. 23], рівноправності громадян щодо отримання медичної допомоги [4, ст. 4]; принцип оновлення та трансформації організації системи охорони здоров'я [5, с. 279]; принцип збереження попереджувально-профілактичного характеру медичного обслуговування населення, тобто визначення сфери охорони здоров'я як комплексного, мультикомпонентного, соціально-орієнтованого середовища [4, ст. 4]; принцип гуманістичної спрямованості системи охорони здоров'я шляхом дотримання пріоритетності загальнолюдських потреб та інтересів над класовими чи загальнонаціональними [4, ст. 4].

Варто зауважити, що в контексті євроінтеграційного вектору реформування вітчизняного соціально-економічного сектору важливе значення мають європейські традиції впливу на якість соціальних послуг та підходи трансформації сфери охорони здоров'я [6]. Таким чином, новоутворені госпітальні округи мають не лише виконувати функції мультикомпонентних об'єднань закладів охорони здоров'я, розміщених в межах певної ОТГ, але і впливати на якість життя громадян України шляхом виконання покладених на них обов'язків та дотримання принципів діяльності.

Питання реформування вітчизняної системи охорони здоров'я уперше було розглянуто в процесі розробки та прийняття Основ законодавства України про охорону здоров'я [5]. Законодавчо обумовлені принципи роботи медичних закладів $є$ достатньо дієвими у практичній діяльності закладів охорони здоров'я, проте сучасна парадигма тран- 
сформації соціально-економічного середовища України визначає нові стандарти та вимоги до їх функціонування. Зокрема, реалізація реформи політичної, адміністративної та фіскальної децентралізації спонукає до розподілу повноважень щодо надання медичної допомоги населенню, тому було запропоновано новітній механізм координації роботи закладів охорони здоров'я на загальнонаціональному та місцевому рівнях - створення госпітальних округів. Процес реструктуризації медичної сфери триває, проте рівень соціального ефекту для населення досі залишається невизначеним.

Ключові причини низької соціальної ефективності медичного обслуговування в Україні, а також передумови проведення медичної реформи та зміни механізму надання медичної допомоги населенню можна об'єднати у дві узагальнюючі групи: фінансово-економічні та соціально-демографічні, характеристика яких наведена на рис. 1.

Досягнення соціального ефекту для населення $\epsilon$ важливим вектором реформаційної стратегії, оскільки усунення існуючих проблем соціально-демографічного характеру може стати не лише методом підвищення якості життя громадян, а і важливим стимулом на шляху сталого загальнодержавного розвитку, а також модернізації традиційних підходів організації медичного обслуговування.

\begin{tabular}{|c|c|}
\hline \multicolumn{2}{|c|}{ 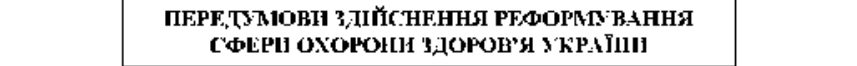 } \\
\hline 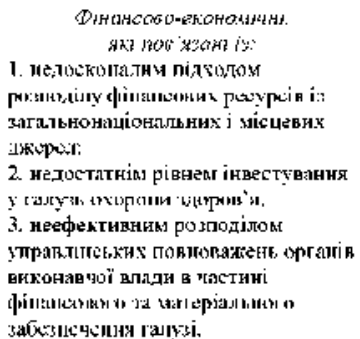 & 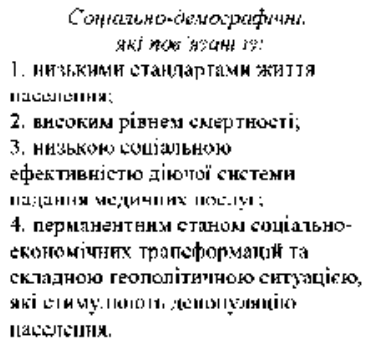 \\
\hline
\end{tabular}

Рис. 1. Основоположні передумови проведення медичної реформи в Україні

Джерело: складено автором за даними [7, с. 51].

Таким чином, сформована структура госпітальних округів впорядкувала механізм фінансування сфери охорони здоров'я на місцях та стала поштовхом для подальшого підвищення результативності меди- 
чного обслуговування жителів ОТГ, зокрема максимізації соціального ефекту від отримання медичних послуг. Структура інвестування у розвиток місцевої медицини передбачає залучення коштів із різних джерел, зокрема державного бюджету, приватних компаній чи домогосподарств. Варто зауважити, що в результаті утворення мережі госпітальних округів частка фінансування у розвиток місцевої медицини зросла: у 2017 році субвенція на розвиток медицини (в т.ч. у сільській місцевості) становила 4,0 млрд. грн., у 2018 році - 5,0 млрд. грн., у 2019 році - 5,0 млрд. грн. Отримані гроші були спрямовані на втілення соціально важливих проектів, реалізація яких мала позитивний вплив на соціально-економічне та демографічне становище в ОТГ. Зокрема, станом на 10.01.2020 року в межах реалізації реформи децентралізації сфери охорони здоров'я було реалізовано 795 стратегічно важливих проектів, з яких 153 передбачали оновлення інфраструктурного забезпечення медичної галузі - реконструкція та капітальний ремонт [8].

Медична реформа досі триває, проте вже сьогодні можна побачити структурні зрушення у структурі медичного обслуговування населення. Соціальний ефект від реструктуризації сфери охорони здоров'я має своє відображення на рівні загального коефіцієнта смертності населення (в т.ч. коефіцієнта смертності дітей у віці до 1 року), а також середній очікуваній тривалості життя при народженні і кількості населення в розрахунку на одного лікаря.

Відповідно до найважливіших показників громадського здоров'я, стан вітчизняної системи охорони здоров'я можна охарактеризувати як недостатньо збалансований, а рівень соціальної ефективності реформаційних заходів низько результативним: протягом досліджуваних років залишається достатньо високий рівень загальної смертності (1 472,7 на 100000 тис. ос. населення підсумками 2019 року). Проте, позитивна тенденція притаманна загальному індексу здоров'я в Україні, який розрахований за результатами загальнонаціональних досліджень, проведених у 2017-2019 роках: станом на 2019 рік показник збільшився на $3,25 \%$ в порівнянні із аналогічним періодом 2018 року. Тому, на нашу думку, сьогоденне проведення реформаційних заходів у сфері охорони здоров'я не матиметь миттєвого соціального ефекту для населення, проте поступова зміна медичного сектору $\epsilon$ запорукою створення новітньої системи медичного обслуговування у майбутніх періодах. 


\section{Література:}

1. Карамишев Д., Удовиченко Н. Основні принципи функціонування системи охорони здоров'я в контексті загальнолюдських цінностей соціальної держави. Медичне право Украӥни: правовий статус пацієнтів в Украӥні та його законодавче забезпечення (генезис, розвиток, проблеми і перспективи вдосконалення): матеріали II Всеукр. наук.-практ. конф., 17-18 квіт. 2008 р., Львів. С. 129-136.

2. Державне управління реформуванням системи охорони здоров'я в Україні : навчально-наукове видання / авт. кол. : М. Білинська та ін. ; за заг. ред. М. Білинської. Київ; Львів : НАДУ, 2012. 240 с.

3. Щирба М. Фінансова доступність охорони здоров'я: проблеми правового статусу пацієнтів. Науковий вісник Ужгородського національного університету. Серія: Право. 2016. № 39 (1). С. 23-26.

4. Основи законодавства України про охорону здоров'я: Закон України від 19.11.1992 № 2801-XII. Available at: https://zakon.rada.gov.ua/ laws/show/2801-12\#Text (дата звернення 11.09.2020 p.)

5. Чернецький В. Принципи організації охорони здоров'я населення. Теорія та практика державного управління. 2012. № 4 (39). C. $278-285$.

6. Дейниховська К. Свропейські принципи та методи функціонування системи охорони здоров'я (на прикладі Франції та Іспанії). Державне будівниитво. 2008. № 2. Available at: http://nbuv.gov.ua/ UJRN/DeBu_2008_2_68 (дата звернення 11.09.2020р.)

7. Юрочко Т. П. Здоров'я населення як стратегічна складова сталого розвитку України. Розвиток людського капіталу: на шляху до якісних реформ / кер. проекту О. Пищуліна. Київ, 2018. С. 49-103.

8. Моніторинг процесу децентралізації влади та реформування місцевого самоврядування: національний проект «Децентралізація» / Міністерство розвитку громад та територій України. Київ, 2020. Available at: https://decentralization.gov.ua/uploads/library/file/ 526/10.01.2020.pdf (дата звернення 11.09.2020 р.) 